\title{
THE USE OF BILINGUAL MAGAZINE AS MEDIA TO DEVELOP THE STUDENTS' VOCABULARY
}

\section{Menggunakan Majalah Dwibahasa Sebagai Media Peningkatan Kosakata Siswa}

\section{Herlina Daddi}

English Education Department, Faculty of Teacher Training and Education Muhammadiyah University of Makassar daddiherlina@yahoo.co.id

\begin{abstract}
This research aimed to explain the improvement of students' vocabulary of noun (abstract noun and concrete noun), Verb (regular verb and irregular verb) and adjective (Descriptive adjective).The method of this research was classroom action research consisted of two cycles. One cycle consist of four meeting. Thus there were eight meetings for two cycles. This classroom action research was done at the second year of SMA Negeri 1 Enrekang. As subject in this research was class XI in 2011/2012 academic year with students' number about 31 students. Those consist of 23 women and 8 men. The instruments of this research were observation sheet and vocabulary test or evaluation. The findings of the research were the students' score in vocabulary mastery through bilingual magazine. Before applying this media in teaching and learning vocabulary, the students' mean score in D-test was 4.6 (poor). After applying bilingual magazine as a media of teaching and learning process, in cycle I the students' mean score improved to 5.35(fair) and then in cycle II also improved to 7.20 (fairly good).
\end{abstract}

Keywords: bilingual magazine, vocabulary.

The comprehension of vocabulary is considered as important part of language learning process or the development of the ability of someone toward language that he/she mastered, the students are usually taught new vocabulary as part of certain lesson and adult people considered that establishment of vocabulary as an interesting and educative activity.

There are many ways which can be applied to improve vocabulary such as: memorizing, translation method, authentic written materials, looking the words dictionary, etc. In this research the writer tries to conduct a technique of teaching vocabulary through bilingual magazine.

In this research, bilingual magazine is meant that the magazine is presented in two language (English and Indonesia) and mutual translating. The article and their meanings are found on the same page, so the words can be known soon.

There are some advantages of bilingual magazine such as: It is easy to get, it is free of charge and distributed to the government instance, local and school 
libraries, the prize is chapter than another magazine in the book stores, stimulate the student' interest to read because it is presented in English band Indonesia and mutual translating.

\section{A. Bilingual Magazine}

\section{Definition Of Bilingual Magazine}

According to Cruzado (1999) bilingual is the capability of communicate, speak, and understanding two languages. The two languages can involve mother tongue and the language that used beside it.

There are some advantages of bilingual magazine such as; it built our brain capability, give more opportunities of employment, it becomes more creative and better in solving difficult problem, and it helps us to communicate with more people.

Devoto (1981) define that magazine is a periodical publication that usually contains miscellaneous collection of articles. Stories, poems, and pictures by different authors that is directed at the general reading public.

Based on the definition above, it is concluded that bilingual magazine is a periodical publication that contains a miscellaneous collection of articles, stories poems and pictures, by different authors that is directed at the general reading public and using two languages.

\section{Kinds of magazine article}

There are many kinds of magazine article are which provides is beneficial especially if you want to work in a magazine industry. Below are the basic type of magazine and their corresponding description:
a. Featurette.
e. Utility
b. Personal skets.
f. Narrative
c. Personal experience.
g. Interviewer
d. Confession.

In the relation to kinds of bilingual magazine article above the researcher will use FEATURETTE as media for teaching English vocabulary because featurette probably the most frequent section arose in magazine. This kind of magazine article will entertain the readers by having the aspect of oddity or humor, and 
sometimes both. And according to the researcher this point will make the student realize and enjoy the learning English vocabulary.

\section{B. The procedure of teaching vocabulary}

Generally in the teaching of vocabulary in the classroom a teacher must follow the procedure describe through the stages below as suggested.

a. Presentation

In this stage how the teacher did entertains this technique there are some techniques such as contextual meaning paraphrasing, definition, realistic, demonstration, gestures, and model.

b. Practice

In this stage can be done by using following types of exercise: complete, matching, close procedure sentence translation, word or vocabulary from the real thing of showing teacher.

c. Production

In this stage the student are expected to apply the learned vocabularies though the speaking activities.

d. The nature of Authentic Material

Hammer (1991) defines that text (either written or spoken) as those which are designed for native speaker; they are real text design not for language student but for the speaker of the language in question. The use of authentic materials is closely associated with the development of the communication approach to language teaching. Cunningswroth in Jemma (2000) state that authentic materials are the materials which originally used in real situation and not design for language teaching. Such materials are used in the classroom to expose learned the real life.

According to Richard and Rodger in Jemma, there are two types of authentic materials, namely:

1) Language- based reality consist of magazine, advertisement, and newspaper.

2) Graphic consist of visual source around with communicative activities can be built such as map, picture, symbols graphs, and charts. 
Some expert have suggest the classification of vocabulary as cited below (hammer, 1991: 159) distinguished two types of vocabulary namely active and passive.

1) Active vocabulary refers to vocabulary that the student have been though or learn and which they are expected to be able to use.

2) Passive vocabulary refers to word which student will recognized, when they met them but which they probably not be able to produce.

Schailinramaty, ( 1995: 10 ) state that every person has types of vocabulary.

1) Active vocabulary is the vocabulary one can produce in speech particularly, but also in unaided writing.

2) Reserve vocabulary, the word we know but we rarely use in speaking we use them in writing.

3) Passive vocabulary, the words we recognize vaguely, but are not surely of he meaning we never use them in other speaking or writing: we just know that have seen them before.

\section{RESEARCH METHODOLOGY}

This research use Classroom Action Research (CAR) method. It aimed to improve the vocabulary achievement of the students through bilingual magazine as a media. In CAR consist of some steps plan, action, observation, and reflection.

The cycle of Class Room Research ( Hopkins, 1993:52 )

\section{Research Subjects}

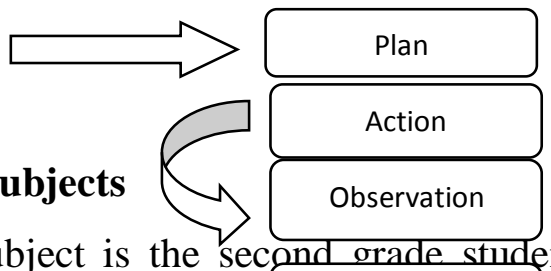

The subject is the sec academic year. There is on Reflection

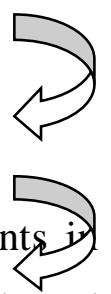
class XI IPA 3 in 2011/2012 this strategy.

\section{Research Instrument}

The researcher instruments which used were:

1. Observation sheet 
Observation sheet aimed to find out the students' data about their percentage and activeness in teaching learning process.

2. Vocabulary test

Vocabulary test aimed to get information about students' improvement after learning process end.

\section{Data Collections}

The technique of data collection in this research is as follows:

1. Observing; it aimed to find out the students' participation during the teaching and learning process.

2. Test; it aimed to finding out the students' competence in learning English vocabulary

\section{Data Analysis}

The data got through the test was analyzed by using the following steps:

1. Calculating the students' correct answer of test.

$$
\text { Score }=\frac{\text { Total correct answer }}{\text { Total test item }} \times 100
$$

2. Calculate the means score by applying the following formula.

$$
\overline{\mathrm{X}}=\frac{\sum x}{N}
$$

where:

$$
\begin{array}{ll}
\mathrm{X} & =\text { the mean score } \\
\sum \mathrm{x} & =\text { Total score of students' responses } \\
\mathrm{N} & =\text { the number of students / sample. }
\end{array}
$$

( Depdikbud, 1985:5)

3. Tabulating and classify the students score into the following classification.

Table 1.classification of students' score

\begin{tabular}{|l|l|l|}
\hline No. & Level & Classification \\
\hline 1. & $96-100$ & Excellent \\
\hline 2. & $86-95$ & Very good \\
\hline 3. & $76-85$ & Good \\
\hline 4. & $66-75$ & Fairly good \\
\hline 5. & $56-65$ & Fair \\
\hline 6. & $46-55$ & Poor \\
\hline 7. & $0-45$ & Very poor \\
\hline \multicolumn{2}{|c|}{ Layman $(1972: 216)$} \\
\hline
\end{tabular}


4. Calculating the percentage of the students' activity in learning process by applying this formula:

$$
\mathrm{P}=\frac{\mathrm{FQ}}{\mathrm{N}} \times 100 \%
$$

Where :

$$
\begin{array}{ll}
\mathrm{P} & =\text { Rate percentage } \\
\mathrm{FQ} & =\text { The frequency of items } \\
\mathrm{N} & =\text { Total numbers of students }
\end{array}
$$

(Hatch and Hansen in M,Yasin,

\section{FINDINGS AND DISCUSSION}

\section{A. Findings}

The findings of the research deal with the answers to problem statement which aims to find the improvement of the students' ability in vocabulary. The result of data analysis in this case by using bilingual magazine can improve the students' vocabulary mastery in term of noun, verb, and adjective at the second year students of SMA Negeri 1 Enrekang. Therefore, for the clear explanation about the students' improvement can be seen in the following table:

1. The improvement of the students' vocabulary ability through authentic material.

Table 2. The mean score of tne students' vocabulary mastery through bilingual magazine

\begin{tabular}{|c|c|c|c|c|}
\hline \multicolumn{3}{|c|}{ Mean Score } & \multicolumn{2}{c|}{ Improvement } \\
\hline D-Test & Cycle I & Cycle II & D-Test-Cycle I & D-Test-Cycle II \\
\hline 4.6 & 5.35 & 7.20 & 0.75 & 7.6 \\
\hline
\end{tabular}

The table above shows the mean score of students' achievement in vocabulary ability. In cycle I vocabulary is taught by using bilingual magazine as a media. 
The topics are taught in cycle I noun, verb, and adjective. In the cycle II is same with cycle I. Vocabulary is tough by using bilingual magazine. The topics taught in the cycle II are noun, verb, and adjective.

Based on the table above, it indicates that the improvement of the students' vocabulary mastery though bilingual magazine is successful. The students' mean score in D-test is 4.6 it is classified in poor score. After students learning vocabulary by using bilingual magazine as a media, there is an improvement in students' vocabulary achievement in cycle I but it is not significant. The students' mean score in cycle I is 5.6 classified into fair score. And in the next cycle, there is an significant improvement: The students' mean score in cycle II is 7.2 classified into fairly good score.

Based to the result of analysis above, it also can conclude that the students' score of cycle I and cycle II is higher than D-test. It mean that there is improved of the students' achievement in vocabulary mastery, it is more clearly showed in the chart below.

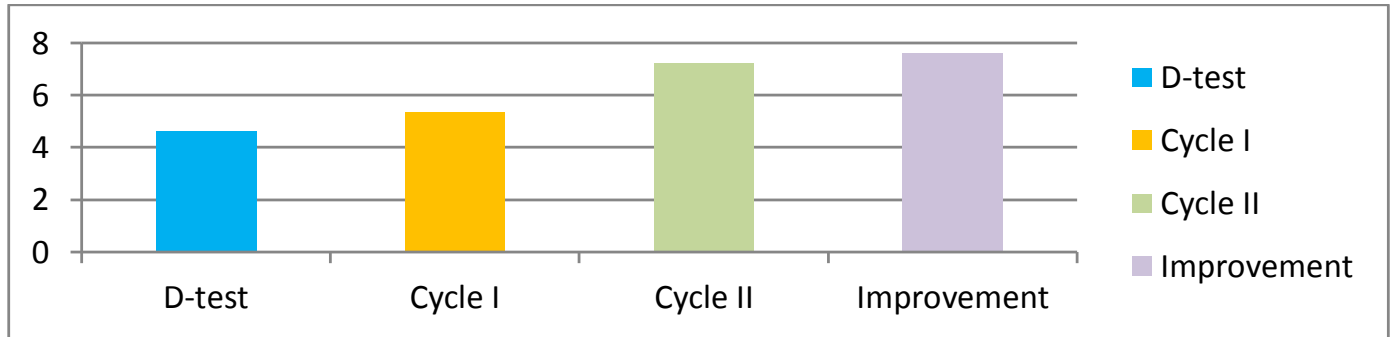

Figure 1: The improvement of students' vocabulary achievement through bilingual magazine.

\section{The students' achievement of vocabulary in translation category.}

Table 3. The mean score of students' achievement in translation category.

\begin{tabular}{|c|c|c|c|c|}
\hline \multicolumn{3}{|c|}{ Mean Score } & \multicolumn{2}{c|}{ Improvement } \\
\hline D-Test & Cycle I & Cycle II & D-Test-Cycle I & D-Test-Cycle II \\
\hline 10.70 & 12.80 & 17.64 & 2.1 & 4.81 \\
\hline
\end{tabular}

The table above shows the mean score of students' achievement of vocabulary in translation category. Based on the table it indicates that the improvement of vocabulary in translation category is success. The students' mean score in D-test is 10.70 , in cycle I is 12.80 and in cycle II is 17.64. So, the improvement of students' vocabulary in translation category is 4.81 . 
Based on the result of analysis above it can be conclude that the students' score of cycle I and cycle II is higher than D-test it mean that there is an improvement of the students' achievement in vocabulary mastery. It is more clearly shown in the chart below:

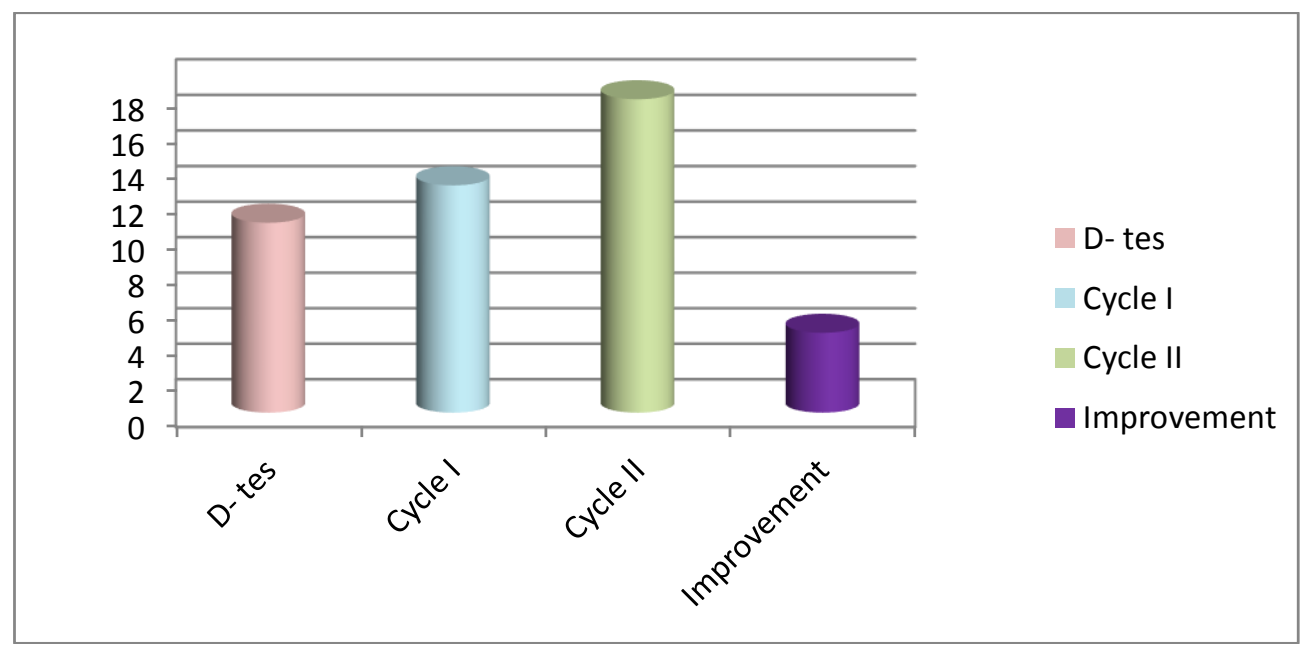

Figure 2: The mean score of students' achievement in translation category.

\section{The students' achievement of vocabulary in classification of words} category

Table 4. The mean score of the students' achievement of vocabulary in classification of words category

\begin{tabular}{|c|c|c|c|c|}
\hline \multicolumn{3}{|c|}{ Mean Score } & \multicolumn{2}{c|}{ Improvement } \\
\hline D-Test & Cycle I & Cycle II & D-Test-Cycle I & D-Test-Cycle II \\
\hline 10.70 & 12.80 & 17.64 & 2.1 & 4.81 \\
\hline
\end{tabular}

The table above shows the mean score of students' achievement in vocabulary in classification of words category. Base on the table above, it also indicates that the improvement of the students' achievement of vocabulary in classification of words category is also successful. In D-test the students' mean score is 10.70 , Therefore, at cycle I, the students' score improve and became 12. 80 , and in cycle II, the students' mean score is 17.64.

Based on the result of analysis above, it can be concluded that the students' score of cycle II is higher than D-test. It means that, there is an 
improvement of the students' vocabulary mastery in translation category. It more clearly shown in the chart below:

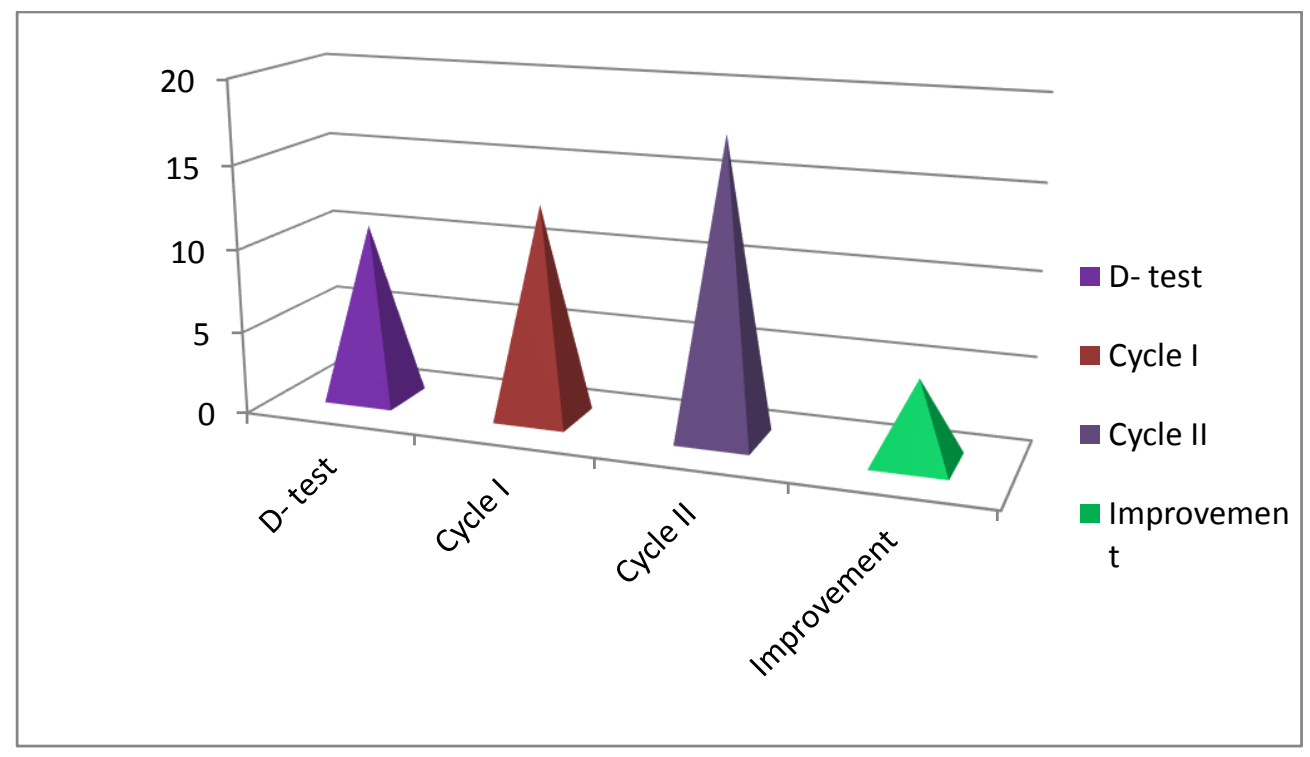

Figure 3: The improvement of students' vocabulary achievement in classification of words category.

1) The students' achievement of vocabulary noun.

Table5. The students' achievement of vocabulary noun

\begin{tabular}{|c|c|}
\hline Cycles & Mean score \\
\hline Cycle - I & 7.75 \\
\hline Cycle - II & 8.36 \\
\hline Vocabulary achievement & 1.13 \\
\hline
\end{tabular}

The table above shows the mean score of students' achievement in vocabulary noun. It indicates that the improvement of the students' vocabulary noun mastery through bilingual magazine is successful. The students' mean score in cycle I is 7.25 and the students' mean score in cycle II is 8.38 it classified into good score. So, the improvement of students' vocabulary noun mastery through bilingual magazine is 1.13 . The data is also shown in the chart below:

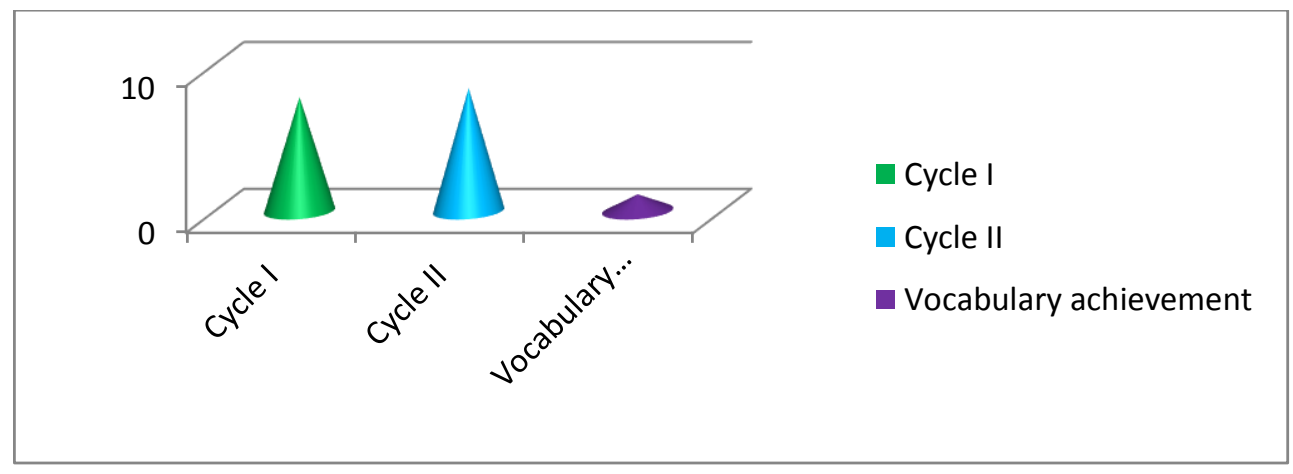


Figure 4: The percentage of students' achievement vocabulary noun

1) The students' achievement of vocabulary verb.

Table 6. The mean score of students' vocabulary verb

\begin{tabular}{|c|c|}
\hline Cycles & Mean score \\
\hline Cycle - I & 6.25 \\
\hline Cycle - II & 7.54 \\
\hline Vocabulary achievement & 1.29 \\
\hline
\end{tabular}

Base on the table above shows that mean score of students' achievement in vocabulary verb. It indicated that the improvement of the students' vocabulary noun mastery through bilingual magazine is successful. The students' mean score in cycle I is 6.25 and the students' mean score in cycle II is 7.54. So, the improvement of students' vocabulary verb mastery through bilingual magazine is 1.29 . The data above is also shown in chart below:

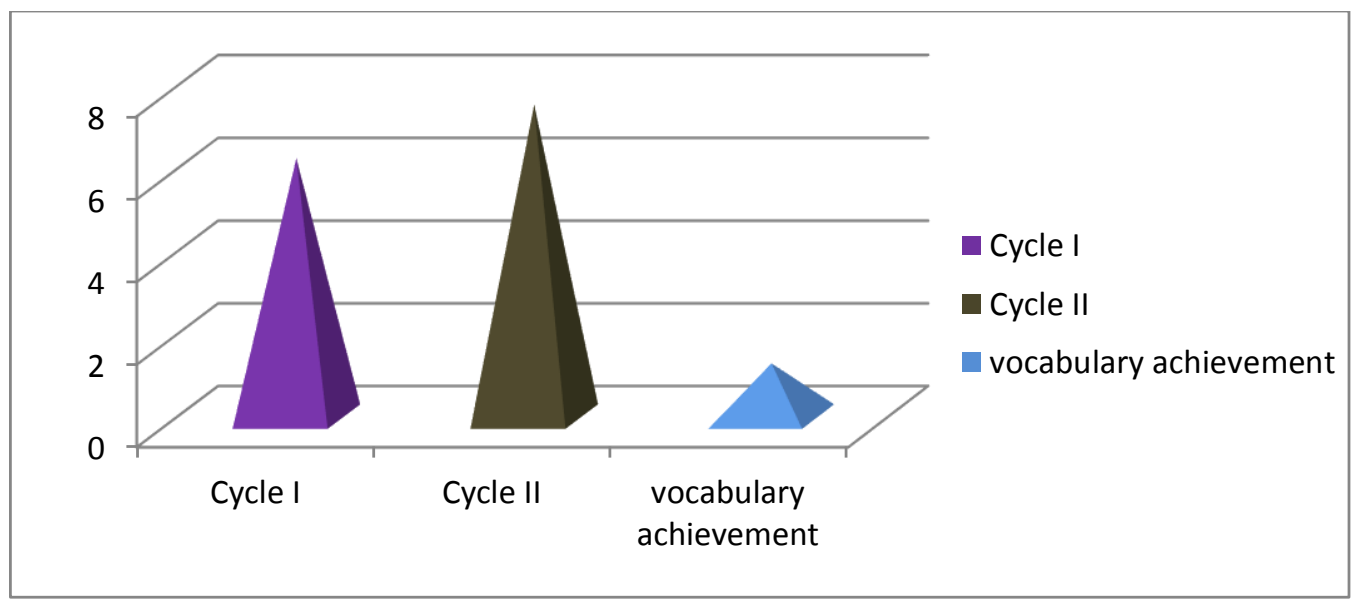

Figure 5. The percentage of students' achievement of vocabulary verb

2) The students' achievement of vocabulary adjective

Table7. The students' achievement of vocabulary adjective.

\begin{tabular}{|c|c|}
\hline Cycles & Mean score \\
\hline Cycle - I & 6.25 \\
\hline Cycle - II & 7.54 \\
\hline Vocabulary achievement & 1.29 \\
\hline
\end{tabular}

In the table above we can see that there is an improvement of the students' vocabulary mastery in term of adjective. After using bilingual magazine in teaching and learning process the students' get successful improvement in 
learning vocabulary adjectives. The students' mean score in cycle I is 6.09 and the students' mean score in cycle II is 8.16 . The table above also shows the students' improvement in vocabulary adjectives. The students' improvement is 2.07 and it is a successful improvement. The chart below also shows the data above:

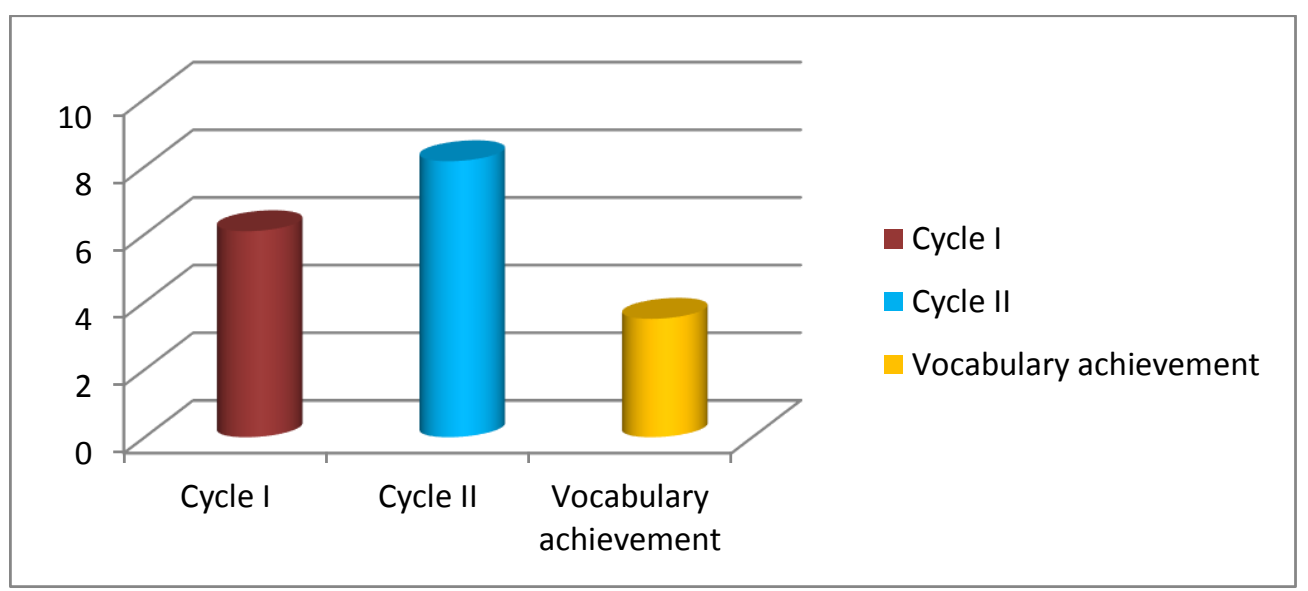

Figure 6. The percentage of students' achievement of vocabulary adjective

a) The percentage of the students' achievement in vocabulary ability through bilingual magazine.

Table 8. The percentage of the students' vocabularyachievement.

\begin{tabular}{|l|l|l|l|l|l|l|l|l|}
\hline \multirow{2}{*}{ No } & \multirow{2}{*}{ Score } & \multirow{2}{*}{ Classification } & \multicolumn{2}{c|}{ D- test } & \multicolumn{2}{c|}{ Cycle I } & \multicolumn{2}{c|}{ Cycle II } \\
\cline { 4 - 9 } & & & Freq & \multicolumn{1}{c|}{$(\%)$} & Freq & \multicolumn{1}{c|}{$(\%)$} & Freq & \multicolumn{1}{c|}{$(\%)$} \\
\hline 1 & $9.5-10$ & Excellent & 0 & $0(\%)$ & 0 & $(\%)$ & 0 & $0(\%)$ \\
\hline 2 & $8.6-9.5$ & Very good & 0 & $0(\%)$ & 0 & $(\%)$ & 0 & $0(\%)$ \\
\hline 3 & $7.6-8.5$ & Good & 0 & $0(\%)$ & 0 & $(\%)$ & 1 & $3.22 \%$ \\
\hline 4 & $6.6-7.5$ & Fairly good & 0 & $0(\%)$ & 0 & $(\%)$ & 24 & $77.41 \%$ \\
\hline 5 & $5.6-6.5$ & Fair & 0 & $0(\%)$ & 15 & $48.38 \%$ & 6 & $19.35 \%$ \\
\hline 6 & $4.6-5.5$ & Poor & 18 & $58.06 \%$ & 15 & $48.38 \%$ & 0 & $0(\%)$ \\
\hline 7 & $0-4.5$ & Very poor & 13 & $41.95 \%$ & 1 & $3.22 \%$ & 0 & $0(\%)$ \\
\hline \multicolumn{2}{|l}{ Total } & 31 & $100 \%$ & 31 & $100 \%$ & 31 & $100 \%$ \\
\hline
\end{tabular}

The table above shows that in D-test, there are 13 students (41.93\%) classify into very poor score, 18 students $(58,06 \%)$ classify into poor score and none studentsclassify into fair, fairly good and another.

The table above also shows the result of students' vocabulary mastery in cycle I and cycle II. In cycle I, there is 1 student (3.22\%)classify into very poor score. 15 
students (48.38) classify into poor score and fair score. And there are none students classify into fair, fairly good and another.

In cycle II none of them classify into very poor score, 6 students (19.35) classify into fair score, 24 students (77.41) classify into fairly good score and 1 student (3.225) classify into good score. And none of studentclassify into very good and excellent score. To shows clearly about the data above, the following chart is presented:

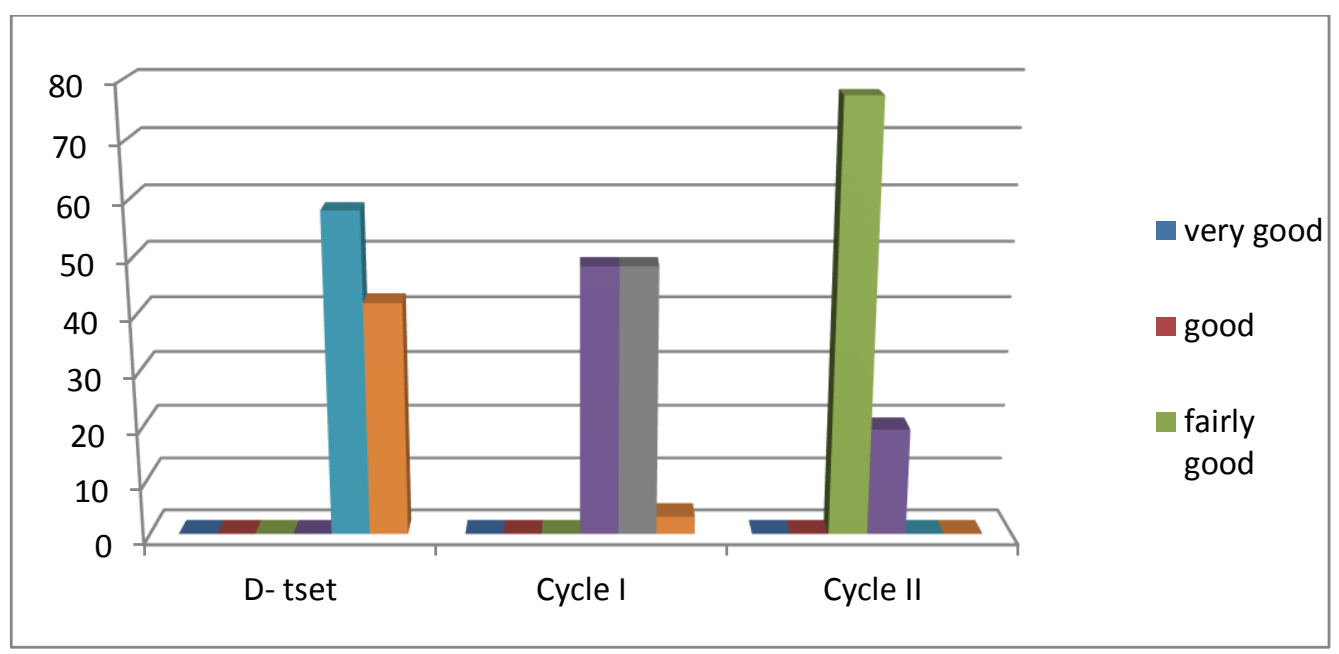

Figure 7. The percentage of students'vocabulary achievement.

b) The Percentage of Students Achievement in Vocabulary Noun.

Table 9. The percentage of student's achievement in vocabulary noun

\begin{tabular}{|l|l|l|l|l|l|l|l|l|}
\hline \multirow{2}{*}{ No } & \multirow{2}{*}{ Score } & \multirow{2}{*}{ classification } & \multicolumn{2}{c|}{ D- test } & \multicolumn{2}{c|}{ Cycle I } & \multicolumn{2}{c|}{ Cycle II } \\
\cline { 5 - 9 } & & & Freq & $(\%)$ & Freq & \multicolumn{1}{|c|}{$(\%)$} & Freq & \multicolumn{1}{c|}{$(\%)$} \\
\hline 1 & $9.5-10$ & Excellent & 0 & $0(\%)$ & 0 & $0(\%)$ & 0 & $0(\%)$ \\
\hline 2 & $8.6-9.5$ & Very good & 0 & $0(\%)$ & 0 & $0(\%)$ & 6 & $19.35(\%)$ \\
\hline 3 & $7.6-8.5$ & Good & 0 & $0(\%)$ & 14 & $45.16(\%)$ & 19 & $61.29(\%)$ \\
\hline 4 & $6.6-7.5$ & Fairly good & 10 & $32.25(\%)$ & 9 & $29.90(\%)$ & 6 & $19.35 \%$ \\
\hline 5 & $5.6-6.5$ & Fair & 12 & $38.70(\%)$ & 4 & $12.90 \%$ & 0 & $0(\%)$ \\
\hline 6 & $4.6-5.5$ & Poor & 9 & $29.03 \%$ & 4 & $12.90 \%$ & 0 & $0(\%)$ \\
\hline 7 & $0-4.5$ & Very poor & 0 & $0 \%$ & 0 & 0 & 0 & $0(\%)$ \\
\hline & Total & 31 & $100 \%$ & 31 & $100 \%$ & 31 & $100 \%$ \\
\hline
\end{tabular}

According to the table above it is shows that in D-test, there are 9 students $(38.70 \%)$ classify into poor score, 12 students (32.25\%) classify into fair score, 10 students classify into good score and none students classify into another 
classification. The table above also shows that, the result of the students' vocabulary noun in cycle I and cycle II. In cycle I, there are 4 students (12.90)classify into poor and fair score, 9 students (29.03\%) classified into fairly good score, 14 students $(45.16 \%)$ classify into good score. And none students classify into very good and excellent score.

In cycle II none of the students classified into very poor, poor and fair score. But 19 students (61.29\%) are classify into good score, and 6 students (19.35\%) classify into very good score. For the clear explanation the chart below will present the data above:

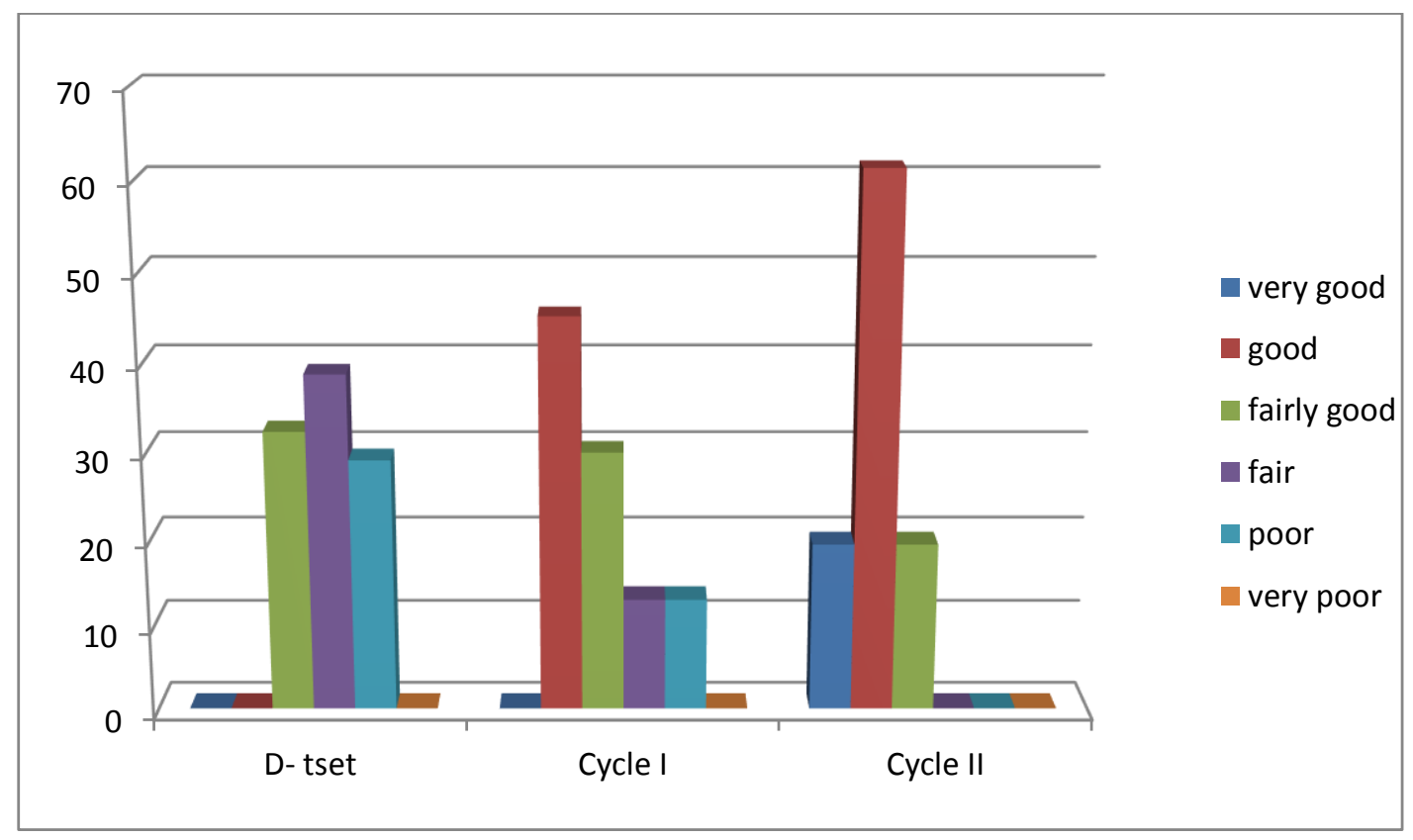

Figure 8. The percentage of students' achievement of vocabulary noun 
b) The Percentage of Students Achievement in Vocabulary Verb.

Table 10. The percentage of students' Achievement in Vocabulary Verb

\begin{tabular}{|l|l|l|l|l|l|l|l|l|}
\hline \multirow{2}{*}{ No } & \multirow{2}{*}{ Score } & \multirow{2}{*}{ Classification } & \multicolumn{2}{c|}{ D- test } & \multicolumn{2}{c|}{ Cycle I } & \multicolumn{2}{|c|}{ Cycle II } \\
\cline { 5 - 9 } & & & Freq & $(\%)$ & Freq & \multicolumn{1}{|c|}{$(\%)$} & Freq & \multicolumn{1}{c|}{$(\%)$} \\
\hline 1 & $9.5-10$ & Excellent & 0 & $0(\%)$ & 0 & $0(\%)$ & 0 & $0(\%)$ \\
\hline 2 & $8.6-9.5$ & Very good & 0 & $0(\%)$ & 0 & $0(\%)$ & 3 & $9.67(\%)$ \\
\hline 3 & $7.6-8.5$ & Good & 0 & $0(\%)$ & 4 & $12.90(\%)$ & 9 & $29.03 \%$ \\
\hline 4 & $6.6-7.5$ & Fairly good & 8 & $25.80(\%)$ & 10 & $32.25(\%)$ & 14 & $45.16 \%$ \\
\hline 5 & $5.6-6.5$ & Fair & 8 & $25.80(\%)$ & 6 & $19.35 \%$ & 5 & $16.12 \%$ \\
\hline 6 & $4.6-5.5$ & Poor & 9 & $29.03 \%$ & 11 & $35.48 \%$ & 0 & $0(\%)$ \\
\hline 7 & $0-4.5$ & Very poor & 6 & $19.35 \%$ & 0 & $0 \%$ & 0 & $0(\%)$ \\
\hline
\end{tabular}

The table above shows that in D-test there are 6 students (19.35) classify into very poor score. 9 students $(29.03 \%)$ students classify into poor score and 8 students $(25.80 \%)$ classify into fair and fairly good score. None of the students classify into good, very good and excellent score.

In relating to the table above also shows that the result of students' vocabulary noun mastery in cycle I and cycle II. in cycle I. there were 11 students $(35.48 \%)$ classify into poor score, 6 students $(19.35 \%)$ classify into fair score, 8 students ( $25.80 \%$ ) classify into fairly good and 3 students $(9.67 \%)$ classify into good score. None of the students classify into very good and excellent score.

In cycle II, there are 5 students $(16.12 \%)$ classify into fair score, 14 students $(45.16 \%)$ classify into fairly good score and 3 students $(9.67 \%)$ classify into good score. And none students classify into another classification. To see the clear explanation, the following chart is presented. 


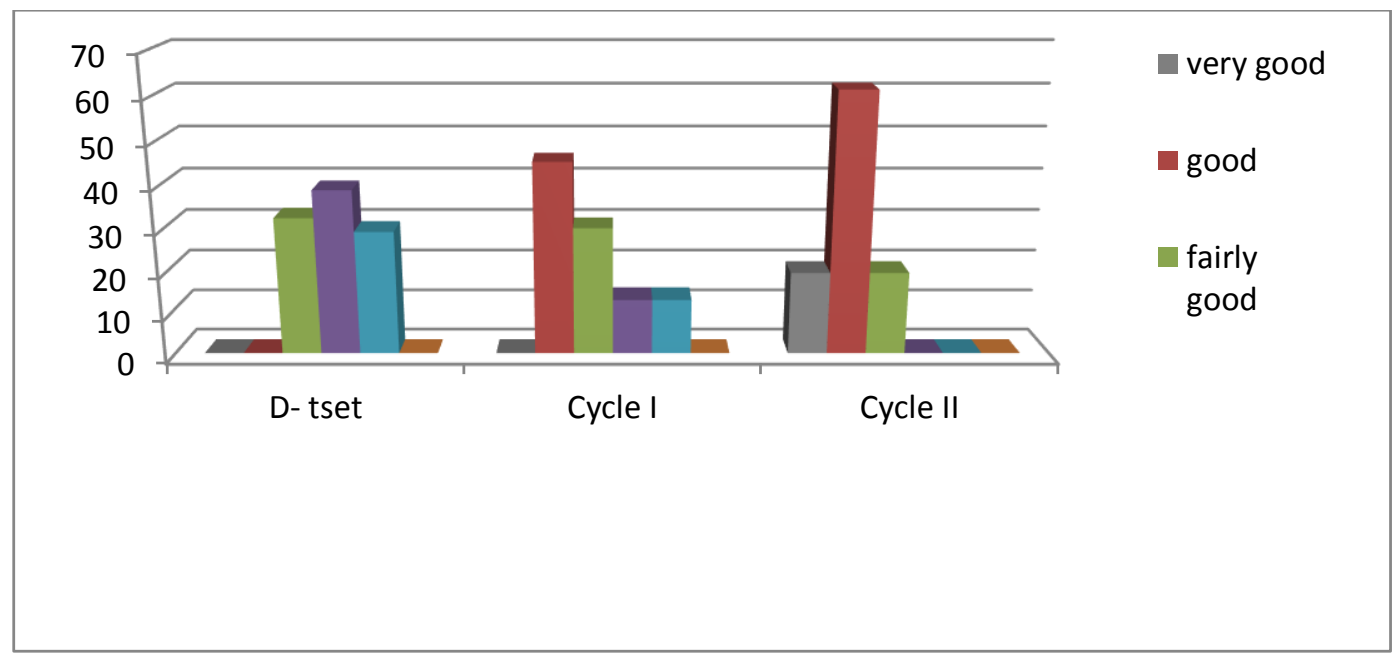

Figure 9. The percentage of students' achievement of vocabulary ver

c) The Percentage of Students' Achievement in Vocabulary Adjective.

Table 11. The percentage of students' achievement in vocabulary adjective

\begin{tabular}{|l|l|l|l|l|l|l|l|l|}
\hline \multirow{2}{*}{ No } & \multirow{2}{*}{ Score } & \multirow{2}{*}{ Classification } & \multicolumn{2}{c|}{ D- test } & \multicolumn{2}{|c|}{ Cycle I } & \multicolumn{2}{c|}{ Cycle II } \\
\cline { 5 - 9 } & & & Freq & \multicolumn{1}{|c|}{$(\%)$} & Freq & \multicolumn{1}{c|}{$(\%)$} & Freq & \multicolumn{1}{c|}{$(\%)$} \\
\hline 1 & $9.5-10$ & Excellent & 0 & $0(\%)$ & 0 & $0(\%)$ & 0 & $0(\%)$ \\
\hline 2 & $8.6-9.5$ & Very good & 0 & $0(\%)$ & 0 & $0(\%)$ & 15 & $9.67(\%)$ \\
\hline 3 & $7.6-8.5$ & Good & 0 & $0(\%)$ & 4 & $12.90(\%)$ & 3 & $29.03 \%$ \\
\hline 4 & $6.6-7.5$ & Fairly good & 12 & $38.70(\%)$ & 7 & $22.58(\%)$ & 11 & $45.16 \%$ \\
\hline 5 & $5.6-6.5$ & Fair & 10 & $32.25(\%)$ & 11 & $35.48 \%$ & 2 & $16.12 \%$ \\
\hline 6 & $4.6-5.5$ & Poor & 9 & $29.03 \%$ & 9 & $29.03 \%$ & 0 & $0(\%)$ \\
\hline 7 & $0-4.5$ & Very poor & 0 & $0 \%$ & 0 & $0 \%$ & 0 & $0(\%)$ \\
\hline & Total & 31 & $100 \%$ & 31 & $100 \%$ & 31 & $100 \%$ \\
\hline
\end{tabular}

In relation to the table above shows the students achievement in vocabulary adjective. This table present that, in D-test there are 9 students (29.03\%) who areclassify into poor score, 10 students (32.25\%)classify into fair score 12 students (38.70) classify in to fairly good score. And none of the students classify into good, very good and excellent score.

Besides that the table above also shows the results of students' vocabulary adjective mastery in cycle I and cycle II. In cycle I, there are 9 students (29.03) classify into poor classification, 11 students (35.48\%) classify into fair score, 7 students $(22.58 \%)$ classify into fairly good score and 4 students (12.90\%)classify into good score. And none of them classify into excellent score.

In cycle II, there are 2 students (6.48\%) classify into fair score, 11 students $(35.48 \%)$ classify fairly good score, 3 students $(9.67 \%)$ classify into good score, 
and 15 students $(48.38 \%)$ classified into very good score. None of students classify into excellent score. According to the data above, we can concluded that there is a significant improvement of students' vocabulary adjective from d- test to cycle I and from cycle I to cycle II. The chart below also will explain about the data above clearly.

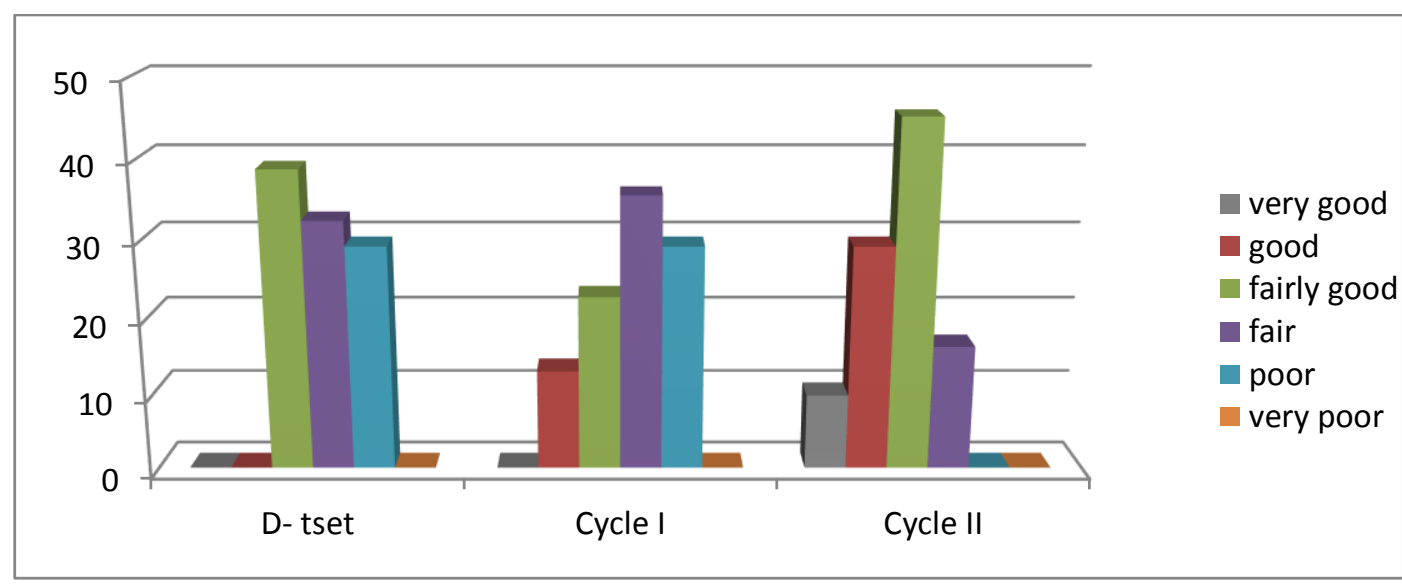

Figure 10. The percentage of students' achievement of vocabulary adjective

The percentage of students' progress in vocabulary mastery through bilingual magazine in d- test up to cycle II

Table 12. The percentage of students' progress.

\begin{tabular}{|c|c|c|c|c|}
\hline \multicolumn{2}{|c|}{ Completeness } & \multicolumn{3}{|c|}{ Students' progress } \\
\hline D- test & Cycle I & Cycle II & D- test - cycle I & D- test - cycle II \\
\hline $0.0 \%$ & $12.90 \%$ & $87.09 \%$ & $12.90 \%$ & $87.09 \%$ \\
\hline
\end{tabular}

Based on the table above the students make an improvement in their vocabulary mastery where in d- test to cycle I is $12.90 \%$ whereas in D-test to cycle II is $87.09 \%$. The chart below will present the data. 


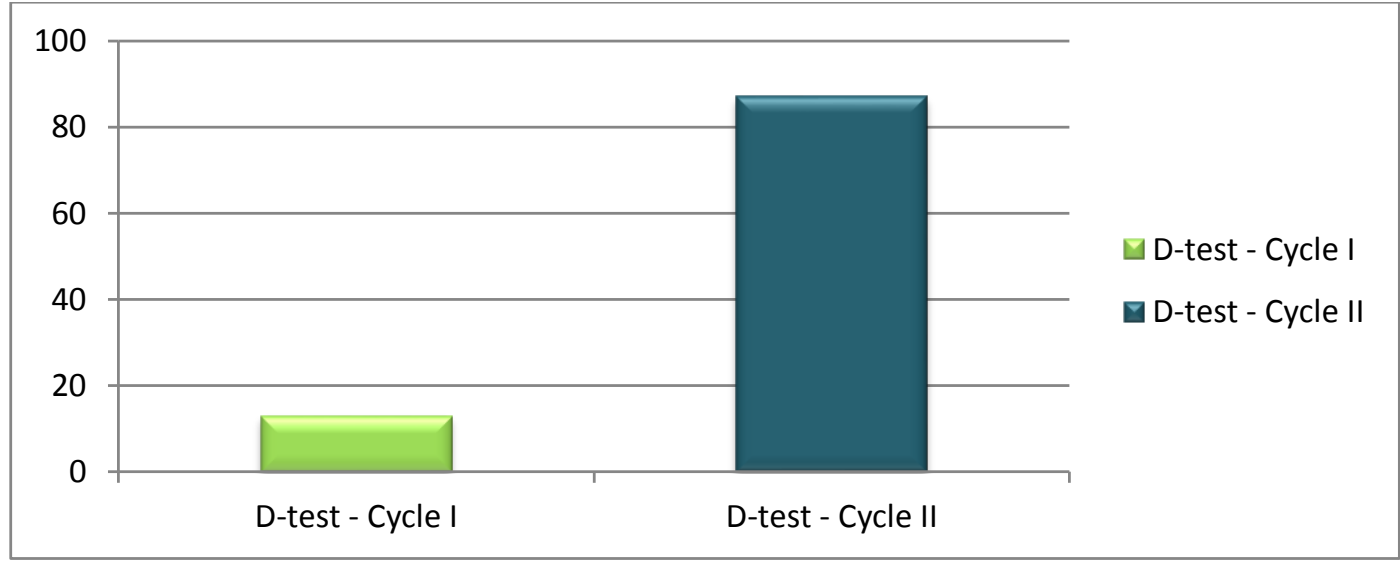

Figure 11. The percentage of students' progress

\section{Observation result.}

The following table and chart shows the observation result of the students' participation in learning vocabulary of the cycle I and cycle II.

Table 12. The percentage of students' participation

\begin{tabular}{|c|c|c|c|c|}
\hline \multicolumn{5}{|c|}{ Student' Participation } \\
\hline \multirow{2}{*}{ Cycles } & \multicolumn{4}{|c|}{ MEETING (\%) } \\
\cline { 2 - 5 } & First & second & Third & Fourth \\
\hline Cycle I & $59.67 \%$ & $58.87 \%$ & $64.45 \%$ & $72.58 \%$ \\
\hline Cycle II & $73.39 \%$ & $78.23 \%$ & $80.65 \%$ & $81.45 \%$ \\
\hline
\end{tabular}

Base on the table above, the students' participation is improved. At the first meeting in cycle I the students' participation is $59.67 \%$ whereas in the last meeting at the cycle II, the students' participation is $81.45 \%$. the data above is also shown in the chart below.

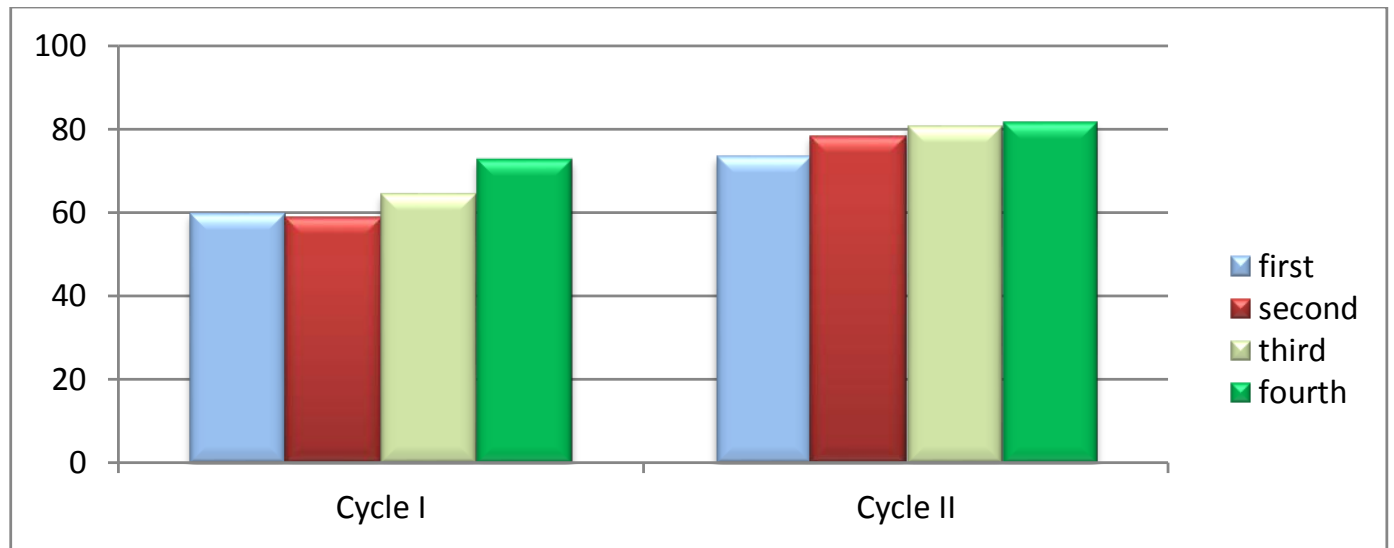

Figure 12. The percentage of students' participation in learning process 


\section{B. Discussion}

Based on procedure of data analysis in the previous section, it can be seen that there is a significant improvement of students' vocabulary ability. Most of students in the cycle II better than cycle I, they can try to find out the new word by using bilingual magazine as a media. Focus on the meaning, enthusiastic, and activeness to memorize the new word in teaching English process.

In the first meeting, there are some problems in teaching and learning process. It is because some of the students are still passive in learning process, student still shy to ask the teacher above their problems and they also can't different between noun, adjective, and verb.

But in cycle II the problems can be on control. In fact, the students very active and quite in learning process and the student could be understand the material, cohesive in their group and also can make sentences base on the words that they found in the bilingual magazine. Because of that, their score in teaching and learning vocabulary of noun, verb and adjective is improved.

1. The improvement of the students' vocabulary mastery through bilingual magazine.

In analysis of the students' achievement, the researcher found that the mean score of students in vocabulary mastery through bilingual magazine is improved. The students' score in D-test is 4.6 (very poor), in cycle I the students' mean score is 5.35 (poor), and in the cycle II the students' mean score is 7.2 (fairly good). The improvement of students' mean score in D-test to cycle I is $0.75 \%$. Whereas the improvement of students' achievement from mean score in D-test to cycle II is $2.6 \%$

During the teaching and learning process in cycle I. the researcher find that, students still difficult to memorize the difficult words. There is no relevance or relation the words and sentences that they make. To solve this problem the researcher had done in cycle II, and revise the previous lesson plan. In this case, the researcher divide into four groups to make the students can correct their words and sentences each other. The researcher also gave deep explanation about the different between noun, verb and adjective that we have found in bilingual 
magazine and we usually find in our daily activities at the school and at home, so the students can understand the vocabulary well.

From the explanation above, the researcher analyzed that through bilingual magazine can improve the students vocabulary mastery in learning the new words, where the students' mean score in cycle I and cycle II is higher than D-test based on the tables in findings.

\section{Observation result}

According to the observation sheet result, the students' participation is increased. The students' participation in the first meeting of the cycle I is $59.67 \%$ and in the last meeting of cycle II, the students participation become $81.45 \%$. It indicates that the application of bilingual magazine in teaching and learning process can stimulate the students' achievement. Beside that the pictures in bilingual magazine will make students enjoy their time while they are in learning and teaching process.

\section{CONCLUSION AND SUGGESTION}

\section{A. Conclusion}

Based on the result of data analysis above, it can be conclude that there are several significant improvements by using bilingual magazine as a media on the students' vocabulary ability. This is shown by the following result.

1. Using bilingual magazine can improve the students' vocabulary mastery at the second year students of SMA Negeri 1 Enrekang in terms of noun, verb and adjective.

2. The students' score vocabulary ability in D-test is 4.6 (poor). In cycle I the students score is 5.35 (poor) and in cycle II the students' score became 7.20 (fairly good). The students' progress from d- test to cycle I is $26.09 \%$ and Dtest to cycle II is $34.78 \%$.

3. By applying bilingual magazine in teaching and learning process will improve the students' activeness in classroom during teaching and learning process.

4. According to the result of observation sheet, it is indicates that by applying bilingual magazine in teaching and learning process can stimulate the students' achievement to learn vocabulary. 


\section{B. Suggestion}

There are a lot of methods that can be used in English teaching and learning process. A bilingual magazine is an alternative method of teaching vocabulary especially in improving the students' vocabulary mastery. Based on this research result, there are some suggestion for the readers and teachers:

1. Bilingual magazine is a good way for students to improve their ability in vocabulary. Using bilingual magazine as a media of teaching helps the teachers as well as the students and give much time to be active in English class.

2. The students should be involved more learning process because it will build up the students' understanding of vocabulary.

3. I expect that this final project would bring new views for all readers and English teachers. Hopefully, there would be other advantages of using bilingual magazine as a media in teaching and learning process.

4. I also expect that this media of teaching and learning process will make the students not only know about the vocabulary but the students also can improve their knowledge by analyze every pictures in the bilingual magazine.

5. Finally, teachers' English classroom should be found another solution to eliminate the students' problems as well as the other aspect of language skills.

\section{REFERENCES}

Arikunto,Suharsimi.2008.Penelitian Tindakan Kelas (PTK). Jakarta: PT. Bumi Aksara.

Baker, Collin. 2001. Foundation of bilingual magazine Education and bilingualism. New York: multilingual Matters publishing.

Baker, Collin and Garcia, Offelia. 2007. Bilingual education an introductory reader, New York: multilingual matters publishing.

Baker, Collin and Garcia, offelia. 2007 Bilingual education and introductory reader, New York: Multilingual matter publishing. 
Cruzado. 1999. Bilingual Magazine targets NH's Growing Latino Community. Article Manchester. (online), Http://www.google.com, accessed 28 February 2009)

Depdiknas. 2005. Garis-garis Besar program pengajaran bahasa inggris. Jakarta; department. Departemen Pendidikan nasional.

Devoto. 1981. Magazine Album. (Online), Http://www.google.com, accessed 28 February 2009)

Encyclopedia, 1971. Encyclopedia of education.

Gay, L.R 1981. Educational Research: Competencies for analysis and Application. Second Edition. Columbus: Charles, Mevil Publishing Company A bell and Howel company.

Harmer, Jeremy. 1991. The practice of English Language Teaching. London: Longman Publishing.

Hatch, Evelin. Anne Larazaton. 1991. The research manual. New York. Newbury House Publisher.

Hornby, A.S 1974. Oxford Advance Learner Dictionary of Current English. London: Oxford University Press.

Smith, DE and Doroty, J. 1982. Analyzing and Training Problem. New York: Hartcourt Brace Jovanovich Inc.

Thomas \& Collier, 2007. Bilingual Education. Wikimedia Foundation, Inc. (Online), (http://www.google.com, accessed 28 February 2009) 